\title{
STRATEGI INDUSTRI PERIKLANAN DALAM MENGHADAPI KHALAYAK SELEKTIF
}

\author{
Shinta Galuh Tryssa \\ Universitas Al-Azhar Indonesia \\ shintagaluhtryssa@gmail.com
}

\begin{abstract}
ABSTRAK
Perkembangan teknologi komunikasi dan informasi saat ini telah memungkinkan khalayak untuk memilah dan memilih berbagai informasi yang ingin diaksesnya, pada media apa serta bagaimana mengaksesnya. Kehadiran internet beberapa dasawarsa terakhir semakin mengukuhkan kedudukan khalayak sebagai pihak yang aktif dan selektif. Industri periklanan harus pula menghadapi selektivitas ini dengan berbagai pilihan media yang semakin berragam. Uses and gratification theory mengatakan bahwa audiens menggunakan media massa untuk berbagai alasan dan pemenuhan kebutuhan. Hal tersebut juga dikuatkan dengan penelitian-penelitian selanjutnya yang dijadikan acuan dalam artikel ini. Dari kacamata industry periklanan, strategi utama yang harus dilakukan adalah melakukan segmentasi pasar, bukan hanya demografis namun meliputi psikografis dan gaya hidup. Strategi lainnya adalah menggunakan konsep pemasaran terpadu, yang tidak melulu mengandalkan media massa. Selain itu, kreativitas juga menjadi strategi lainnya guna menarik perhatian khalayak dan memunculkan aspek entertainment dalam membuat iklan.
\end{abstract}

Kata kunci : Selektivitas Khalayak, Industri Periklanan, Strategi Periklanan. 


\section{PENDAHULUAN}

Kemajuan teknologi informasi saat ini sangat memudahkan khalayak untuk mengakses informasi secara cepat, jauh lebih cepat daripada dekade lalu. Hal ini menyebabkan banyaknya pilihan jenis serta konten media yang ditawarkan kepada khalayak. Jumlah stasiun TV di Indonesia semakin bertambah, bukan hanya yang bersifat nasional akan tetapi geliatnya mulai terasa di daerah bahkan sampai ke komunitas. Hal ini bisa dilihat dari jumlah anggota ATLI (Asosiasi TV Lokal Indonesia) yang sampai saat ini tercatat 29 TV lokal, dengan 2 TV yang karena sebab tertentu tidak bersiaran (atvli.com, 2010). Sedangkan untuk TV komunitas, salah satunya adalah Grabag TV, TV komunitas di desa Grabag, 30 kilometer arah timur laut kota Magelang, daerah yang sebenarnya merupakan blankspot (Gatra.com, 2009).

Munculnya provider TV berbayar yang menawarkan berbagai penawaran khusus dengan harga murah juga menambah daftar pilihan media serta konten yang tersedia. Bahkan, karena harganya yang terjangkau, tak jarang ditemui rumah-rumah kontrakkan di gang sempit yang tidak bisa dimasuki mobil, saat ini dengan mudahnya mengakses siaransiaran dari luar. Hal ini berarti pilihan jenis serta konten media telah memasuki sampai pada tataran masyarakat kelas menengah.

Era digital yang ditandai dengan munculnya internet, semakin memanjakan khalayak dengan kemudahan akses, harga yang terjangkau serta ragam dan jenis informasi yang seakan "dihamburkan" di dunia baru yang maya tersebut. Melalui internet, akses terhadap televisi dan radio bisa diakomodir melalui live streaming, serta akses tehadap koran dan majalah melalui e-paper. Saat ini pun rasanya mustahil menemukan perangkat telepon seluler yang tidak memasukkan fitur internet di dalamnya.

Gaya hidup, kebiasaan, hingga kecenderungannya terhadap media dan konten media pun berubah. Sejalan dengan apa yang diyakini oleh McLuhan (Lister, Dovey, et al, 2003), perlahan-lahan perkembangan teknologi informasi menciptakan kebudayaan baru (Tofler dalam Rachmat, 1997). Dengan adanya internet pula, khalayak kini bebas memilih, memilah jenis informasi apa yang ingin dikonsumsi, kapan serta bagaimana mengonsumsinya. 'Bola' saat ini ada di tangan khalayak. Apakah khalayak memilih AXN atau memilih siaran nasional, apakah khalayak memilih membaca Kompas atau sekedar mengaksesnya di kompas.com.

Pengiklan, dalam hal ini harus lebih cerdas dan cerdik menghadapi khalayak yang juga semakin cerdas dan cerdik dalam mengakses informasi. Khalayak tentu tidak akan menghabiskan waktu mereka yang berharga di jaman serba instan hanya untuk menonton jeda komersial yang bisa menghabiskan setengah jam dari tayangan prime time. 
Namun demikian, sejumlah fakta seperti kenaikan rata-rata belanja iklan pada 2009 (Reynaldi, 2009), serta mulai maraknya mobile marketing (Marketing Mix, 2010) menurut penulis menunjukkan bahwa industri periklanan tidak pernah kehilangan kekuatannya dalam menarik khalayak. Dimana ada media yang dikonsumsi oleh khalayak, di situ iklan akan selalu mencari cara untuk hadir.

Tulisan ini bertujuan untuk mengetahui bagaimana strategi industri periklanan menghadapi 'obstinate audience' (Meurs, 1998). Apakah strategi tersebut pada akhirnya membuat sebuah manipulasi dan mampu menciptakan perasaan butuh dalam diri khalayak sehingga belanja iklan meningkat dan diskon besar-besaran selalu didatangi pengunjung? Dalam makalah ini, penulis mencoba untuk meninjau dari dua sisi, sisi teoritis berdasarkan teori-teori yang relevan serta penelitian-penelitian serupa dan sisi praktis berdasarkan interviu dengan $\mathrm{NH}$, praktisi periklanan yang sudah puluhan tahun malang melintang di dunia pariwara.

\section{TINJAUAN PUSTAKA}

\section{Penelitian Sebelumnya}

Penulis menggunakan hasil penelitian serupa sebagai bahan acuan. Dalam hal ini, peneliti merujuk pada disertasi Lex Van Meurs (1998) yang berjudul, "Switching during Commercial Breaks". Hasil penelitian tersebut menguatkan proposisi bahwa khalayak adalah individu-individu yang selektif yang membuat pilihan untuk mengganti atau tidak mengganti saluran berdasarkan kesadaran. Namun demikian, iklan yang dianggap mengganggu tidak serta merta menjadi alasan khalayak untuk mengganti saluran. Pilihan untuk mengganti saluran saat jeda iklan cenderung bergantung pada program acara itu sendiri.

Dalam kesimpulannya mengenai selektivitas pemirsa, Meurs (1998) mengatakan, "From the analysis, it can be concluded that people do not watch advertising so much out of habit but that they base their choice to continue watching or to switch on the programming on offered at that moment. If selectivity in television viewing is defined as the conscious selection of the spesific programme on the basis of the programming on various channels, then this study supports the proposition that television viewing in many instances is a selective activity, whether it involves deciding to switch away or not. The choice to switch or remain is largely based on the programming on the channel being watched and on the channels broadcasting opposite it"

Penelitian Meurs tersebut jelas menunjukkan adanya selektivitas khalayak, atau yang kerap disebut dengan selective exposure. Media yang dijadikan objek dalam penelitian Meurs adalah televise, sebuah media konvensional yang sempat dianggap mempunyai 
kekuatan dominan atas diri khalayak yang salah satunya adalah mendorong perilaku agresif pada anak-anak (Ashford dan Leroy, 2008).

Dalam kaitannya dengan internet, penelitian yang dilakukan oleh Dr. Jin Yang yang dimuat pada Journal of New Communication Research edisi 2007 - 2008 (Yang, 2008), semakin mengonfirmasi kedudukan khalayak sebagai pihak yang aktif dan selektif. Penelitian tersebut menyimpulkan bahwa pengguna internet, khususnya berita online selektif dalam memilih topic berita yang akan mereka konsumsi. Para responden dalam penelitian tersebut juga disebutkan hanya membaca topic-topik tertentu yang relevan dengan kehidupan mereka. Selain itu, faktor-faktor demografis seperti usia dan pendidikan, sedikit banyak mempengaruhi selektivitas tersebut.

\section{Khalayak Aktif dan Selektif, Sudut Pandang Teoritis}

Berangkat dari riset klasik mengenai alasan penggunaan media oleh khalayak, teori Uses and Gratification berkembang dan masih digunakan sampai saat ini. Teori ini bisa dikatakan sebagai salah satu teori awal yang memandang khalayak sebagai individuindividu yang aktif dan selektif. Teori ini memiliki sejumlah asumsi dasar (Mc Quail, 2005):

- Pilihan terhadap media serta isi media oleh khalayak didasarkan pada pemikiran yang rasional serta berorientasi tujuan, yaitu sebagai pemenuhan kebutuhan.

- Khalayak menyadari kebutuhannya dalam kaitannya dengan media. Kesadaran ini timbul baik dari faktor personal maupun sosial.

- Kebutuhan personal khalayak merupakan faktor penentu yang lebih signifikan dibandingkan dengan faktor estetika atau budaya.

- Seluruh atau sebagian besar faktor yang relevan bagi pembentukan audiens pada prinsipnya dapat diukur.

Asumsi bahwa khalayak aktif dan memiliki pilihan mereka sendiri juga terdapat dalam Expectancy-Value Theory (Meurs, 1998). Terdapat dua pengaruh kognitif yang memotivasi perilaku khalayak, sebagaimana disebutkan dalam teori tersebut, yaitu ekspektasi, serta nilai. Penilaian akan kesuksesan sebuah kegiatan (ekspektasi) berkaitan dengan alasan (nilai) seseorang terlibat dalam kegiatan tersebut (Elliot dan Dweck, 2005). Secara singkat, teori ini mengatakan bahwa khalayak membuat pilihan, dalam hal ini mengonsumsi media, berdasarkan pada persepsi dan ekspektasi mereka mengenai keuntungan yang mereka dapatkan serta nilai-nilai mereka.

Apabila merujuk pada asumsi di atas, maka kebutuhan khalayak adalah faktor penentu bagi penggunaan media oleh khalayak. Khalayak-lah yang melakukan pilihan terhadap informasi-informasi yang ia butuhkan atau tidak. Apabila khalayak tidak menemukan pemenuhan kebutuhan ketika melihat iklan di televisi, mereka akan segera mengganti saluran. 
Levy dan Windahl (Ou.edu, 2010) merumuskan tiga fase dalam proses selektivitas khalayak, bergantung pada waktu terjadinya terpaan media. Fase pertama adalah pra terpaan media. Selektivitas di sini mencakup pemilihan isi pesan media massa. Fase kedua adalah fase saat terjadinya terpaan media. Selektivitas di sini mencakup keterlibatan personal dan psikologis khalayak. Meurs (1998) mengatakan hal ini juga mencakup bagaimana khalayak mengonsumsi media. Fase terakhir adalah fase pasca terpaan media, yaitu perilaku khalayak setelah terpaan media terjadi. Meurs memberi contoh dengan selektivitas ingatan terhadap terpaan media.

Khalayak iklan adalah individu-individu aktif dengan segala proses internal dalam dirinya, baik itu sisi kognitif maupun sisi afektif. Artinya, khalayak-lah yang akan menentukan apakah suatu informasi yang diberikan media massa dibutuhkan atau tidak, sesuai atau tidak dengan nilai-nilai yang ada dalam dirinya, dan banyak faktor lainnya. Dengan kata lain, khalayak adalah pribadi aktif dan selektif dan akan menghindari iklan apabila mereka menganggapnya sebagai informasi yang tidak mereka butuhkan.

\section{Habitus dan Ruang Sosial}

Penulis menggunakan pandangan Pierre Bordieu untuk menjelaskan thesis penulis mengenai manipulasi makna oleh industri periklanan. Bordieu dalam Piliang (1997) membagi dua hal dalam kehidupan sosial: habitus dan field. Habitus mengacu pada situasi, aksi, prosedur, praktik-praktik keseharian yang mengikuti jenis dan gaya hidup tertentu. Habitus menempatkan posisi seorang individu di dalam dunia kemasyarakatan (posisi, gender, kelas, ras status, dan sebagainya).

Habitus hadir dalam segala sendi kehidupan manusia: cara bicara, cara makan, cara berpakaian, sampai dengan cara berjalan. Habitus dan cara bekerjanya hadir tanpa kita sadari (Badriaty, 2006).

Ruang ( field) dideskripsikan Bordieu dengan suatu arena sosial yang di dalamnya terjadi perjuangan atau manuver memperebutkan sumber atau pertaruhan dan akses terbatas. Sementara itu, perjuangan merupakan praktik sosial seseorang atau kelompok. Praktik sosial tak lain tak bukan adalah produk interaksi antara habitus dan field.

Menurut Henry Lefebvre (dalam Piliang, 1997), ruang (sosial) adalah produk (sosial). Artinya, ruang itu diproduksi secara sosial oleh masyarakat. Ruang merupakan cermin dari tatanan sosial, ekonomi dan politik suatu masyarakat. Sebagai produk sosial, ruang kerap dijadikan sebagai alat kontrol, dominasi dan kekuasaan (Frederik dalam Piliang, 1997). Ruang adalah arena perebutan simbol dan ideologi.

Media massa dalam perannya terhadap keragaman disebutkan harus dapat berfungsi sebagai cermin, baik dari struktur maupun kontennya, dari tatanan sosial, ekonomi dan kebudayaan masyarakat secara proporsional (Mc Quail, 2005). Dari sini dapat disimpulkan bahwa merid massa adalah sebuah ruang sosial. Di dalamnya terdapat 
perebutan simbol dan ideologi. Ada sebuah ideologi tertentu yang kemudian mendominasi, memanipulasi pola pikir khalayak, menanamkan nilai-nilai yang mana yang ideal, mana yang baik dan mana yang buruk.

\section{Kekerasan Simbolik dalam Iklan}

Iklan, dengan menggunakan media, apakah itu media luar ruang, ataukah media massa; di dalamnya terdapat upaya untuk menanamkan nilai-nilai tertentu kepada khalayak. Dalam hal ini, pesan iklan menjadi ideologi dominan yang menentukan mana yang ideal dan mana yang tidak.

Disinilah muncul kekerasan simbolik. Kekerasan simbolik merupakan bentuk lunak dari kekerasan. Ia berupa tindakan langsung yang umumnya melalui mekanisme kultural dan berbeda dengan bentuk-bentuk kontrol yang lebih langsung yang sering menjadi sasaran perhatian sosiolog (Ritzer dan Goodman, 2004: 526, dalam Badriati, 2006).

Badriati (2006) mengatakan bahwa bahasa yang halus, gaya bahasa - gaya komunikasi yang tidak terus terang atau tidak langsung, eufimisme bisa memuat aspek kekerasan manakala termuat sebuah kepentingan kelompok. Iklan merupakan pesan-pesan yang hendak disampaikan oleh kelompok pemilik modal kepada khalayaknya. Pesan-pesan itu dikemas dalam bentuk perempuan bertubuh langsing yang mengatakan bahwa, "langsing saja tidak cukup", untuk membentuk pikiran di benak target marketnya - perempuanperempuan yang sudah langsing- bahwa tubuh langsing mereka tidak cukup, mereka harus menggunakan produk pengiklan yang berguna untuk 'mencukupi' apa yang tubuh langsing mereka tidak bisa mencukupi, yaitu pengencang otot.

\section{Kacamata Pelaku Industri Periklanan}

Penulis melakukan wawancara dengan $\mathrm{NH}$, pemilik salah satu pionir perusahaan periklanan dalam negeri, di kediamannya di bilangan Bintaro, Jakarta selatan. Di tengah kepungan agensi periklanan asing, agensi milik NH dapat dikatakan 'papan atas' dan banyak menangani perusahaan-perusahaan besar. NH sendiri sudah lama berkecimpung di dunia periklanan dan sudah dikenal di kalangan pegiat pariwara. Di bawah ini adalah analisis penulis terhadap hasil wawancara dalam kaitannya dengan permasalahan pada tulisan ini.

Dari kacamata industri periklanan, iklan tidak akan pernah mati. $\mathrm{NH}$, menyebutkan contoh salah satu media massa. Televisi, dikatakannya, tidak mungkin hidup tanpa iklan. Begitupun perusahaan periklanan tidak mungkin hidup tanpa pengiklan (produsen barang/jasa, red.). Dan perusahaan pun akan selalu membutuhkan iklan untuk menjangkau pembeli maupun calon pembeli. Perubahan pola konsumsi media khalayak dengan adanya media baru (internet) dirasanya tidak akan mematikan media-media konvensional. Yang artinya, iklan pun tidak akan pernah mati. 
NH mengatakan,

"Iklan itu kan awalnya berkembang dari outdoor. Outdoor itu kan berkembang sekali dan sampai sekarang masih ada. Kemudian baru ke cetak, kemudian televisi. Orang mengatakan pada saat iklan televisi muncul, iklan cetak akan mati, bahkan saat internet masuk, katanya koran akan mati karena katanya orang udah males baca harus bayar. Dengan internet kita bisa langsung baca dan seterusnya... Tapi ternyata enggak."

Memang kenyataannya, media luar ruang, media cetak, radio dan televisi masih bisa mempertahankan eksistensinya dengan membuat sedikit perubahan. Kompas misalnya, untuk dapat mengakomodir khalayak yang aktif dengan ritme hidup tinggi, kemudian membuat kompas.com, serta menyediakan fitur multimedia berupa kode pada berita tertentu di versi cetaknya yang bisa langsung mengeluarkan link ke situs yang memuat berita tersebut apabila difoto menggunakan ponsel.

Artinya, iklan akan selalu bisa menyesuaikan diri pada apapun bentuk media. Yang mungkin berubah, menurutnya, adalah bargaining position-nya. Narga Habib menyebutkan,

"belanja iklan di Indonesia kasarnya setiap tahun itu double digit prosentasinya, 20-an \% rata-rata. Saya nggak tau 2009 dibandingkan 2008, tapi rasanya 20-an persen sih dia ... Pertanyaannya, ini yang saya pertanyakan dari dulu angka tersebut adalah datangnya dari sebuah badan internasional Nielsen, dan angka yang diangkat adalah berdasarkan gross rate adalah publish rate.. Yang kita tidak tahu adalah actual atau nett-nya sebenarnya berapa. Apakah memang juga tumbuh double digit, atau karena persaingan antar TV akhirnya motong2 harga. Paling gampang, angka yang dipublish oleh Nielsen itu kita cut at least 60\%, at least. Jadi, nilainya sebenarnya lebih kecil dari angka yang dipublish, karena persaingan. Bahkan, ada ststion2 TVyang saya katakana saya punya komitmen X rupiah untuk 3 bulan, saya bisa mendapatkan diskon, total keseluruhannya itu 90 persen. Rasanya sih kalo dibilang tumbuh, rasanya sih nggak seperti yang dibilang itu, malah mungkin nggak tumbuh. Jumlah spotnya iya, tapi nilai rupiahya yang berkurang, karena... Kemudian larinya ke media-media yang lain..."

Dalam analisis penulis, di sini berlaku hukum ekonomi. Karena kebutuhan iklan yang besar dari sejumlah stasiun TV, maka beberapa stasiun TV menyediakan paket diskon sehingga seolah-olah belanja iklan bertambah, padahal sebenarnya hanya spot iklan saja yang bertambah, akan tetapi nilai sebenarnya tidak terukur karena lembaga survey AC Nielsen hanya menggunakan gross rate.

Memang diakui $\mathrm{NH}$, ada sedikit perubahan semenjak muncunya social media network. Artinya, keberadaan khalayak yang mungkin lebih sering mengakses Facebook atau 
kaskus.us daripada membaca koran sudah mulai dilihat oleh pengiklan. Dan lonjakannya besar, walaupun secara umum belum berarti apabila dibandingkan dengan belanja iklan di televisi yang mencapai kurang lebih $60 \%$ dari total belanja iklan di media massa.

“...cuma masalahya adalah iklan yang seperti apa dan media apa yang dipake? Kalo misalkan sekarang kita bilang kita ngotot mau keluar dengan iklan di televisi, terus ternyata audiens kita sudah tidak arahnya ke sana, sudah beralih sekarang. Social media network itu sekarang sudah menjadi acuan walaupun nilainya masih sangat kecil, tapi kita bisa lihat lompatan nilainya itu double digit.", ujar ayah tiga anak ini.

Khalayak bagi industri periklanan adalah hal paling utama yang harus dilihat, karena sebenarnya 'hidup-matinya' pengiklan, perusahaan iklan, dan media massa adalah dari khalayak itu sendiri. Oleh karena itu, audience oriented adalah prinsip utama industri periklanan. NH menyebutnya dengan prinsip "follow him", dimana "him" di sini merujuk pada khalayak. Artinya, dalam menetapkan strategi periklanan yang pertama harus dilihat adalah unsur-unsur yang ada dalam diri khalayak, dan itulah yang harus dituju dan di-follow. Penggemar motor besar ini kemudian menjelaskan, “...karena di kita, di CR (nama agensi iklannya, pen.), kita bicara sebuah prinsip yaitu follow him. Him itu adalah konsumen. Kita bicara dengan target, segmentasinya seperti apa. Segmennya yang berubah, audiensnya yang berubah. Kalau jaman dulu kita tabur, kalo sekarang enggak, kita segmented. Brand yang sama bisa jadi punya target tua, muda... Dulu cukup dengan demografis, sekarang udah lebih psikografis, itu juga ada turunan-turunanya, sehingga menjadi compliment each other".

Menghadapi 'musuh terbesar' pengiklan televisi, remote control, memang ada sejumlah pengiklan yang mem-block slot iklan pada waktu-waktu tertentu di semua stasiun TV. Sehingga kapan pun khalayak mengganti saluran TV, khalayak akan menyaksikan pesanpesan dari produsen tertentu. Akan tetapi, menurut NH, strategi tersebut membutuhkan biaya yang sangat besar. Ditambah, apabila dilihat dari efektivitas, strategi semacam itu tidak sepenuhnya efektif.

Alih-alih, menurut $\mathrm{NH}$, ada hal lain yang mungkin dapat lebih menarik perhatian khalayak, yaitu aspek entertainment dari sebuah iklan. Salah satu unsur penting dalam sebuah iklan adalah bahwa sebuah iklan harus entertaining sehingga khalayak tidak langsung memindahkan channel ketika muncul jeda komersial. Di sini, sangat dituntut kreativitas agen periklanan. Sayangnya, menurut pria yang pernah mengenyam pendidikan seni rupa di ITB ini, banyak iklan kurang memperhatikan unsur kreativitas dan hanya berupa pesan dari produsen produk saja.

Berdasarkan pengamatan penulis, industri periklanan papan atas saat ini bukan hanya melayani iklan di media massa atau media luar ruang; akan tetapi industri periklanan tersebut lebih menggunakan pendekatan langsung kepada target market melalui 
Intergated Marketing Communication yang mencakup di dalamnya komunikasi lini atas dan lini bawah.

Bicara tentang target market, menurut $\mathrm{NH}$, apa yang harus diberikan perusahaan iklan kepada pengiklan sebagai kliennya bukan hanya keinginan klien; tetapi juga kebutuhan klien, walaupun terkadang keduanya tidak seiring sejalan. NH memberi contoh, berbeda dengan pengiklan kebanyakan yang sering menggunakan selebriti sebagai strategi menyampaikan pesan, ia justru memilih tidak menggunakan selebriti untuk sejumlah alasan. Tidak dapat dipungkiri, menggunakan selebritis mungkin bisa mencuri perhatian pemirsa, akan tetapi apakah pesan yang disampaikan pengiklan bisa sampai? Atau jangan-jangan penggunaan selebritis malah sekedar menjadi distraction, sehinga pesan iklannya tidak dipahami khalayak. Alasan berikutnya adalah selebriti adalah figure publik yang segala tindak tanduknya disorot media massa, sehingga adakalanya sosok selebriti ini terpapar isu-isu miring terkait dirinya. Mulai dari ranah yang paling pribadi seperti perceraian, hingga pengunaan obat-obatan terlarang. Apabila hal ini terjadi, justru bisa merusak reputasi brand sebuah produk.

Salah satu kalimat yang sering diulang-ulang NH selama wawancara berlangsung adalah, "Insight kita analisis, kemudian kita keluar dengan sebuah foresight". Insight di sini, apabila mengacu pada Insight Triangle Concept, merupakan pengetahuan dan pemahaman mendalam mengenai konsumen dan konteksnya. Artinya, pembuat iklan sebelumnya mungkin harus menyelenggarakan riset pasar untuk mengetahui sisi-sisi terdalam konsumen. Sisi-sisi terdalam ini bisa mencakup banyak hal, mulai dari psikologis, pengalaman individu, pengaruh budaya, dan lain-lain.

Hal tersebut dilakukan karena seperti penulis, sebutkan sebelumnya, strategi utama dalam periklanan adalah mengikuti khalayak. Saat ini bukan saatnya lagi bagi pengiklan untuk belanja iklan 'sembarangan' di banyak media. Pengiklan melalui perusahaan periklanan-nya atau konsultan komunikasi-nya harus mengetahui terlebih dahulu siapa khalayaknya, siapa segmentasi pasarnya.

Segmentasi khalayak yang berbeda tentu mengakses media yang berbeda pula. NH memberi contoh, Kompas boleh dibaca oleh 100.000 pembaca nasional; akan tetapi apakah produk yang menyasar ke konsumen remaja cocok untuk beriklan di Kompas? Berapa persen dari 100.000 pembaca tersebut yang remaja?

Strategi yang cocok untuk segmentasi pasar tertentu akan diketahui setelah insight dianalisis. Hal ini juga yang boleh jadi membuat beberapa pengiklan mungkin lebih cocok dengan pendekatan yang 'sedikit' lebih 'humanis', seperti direct selling dengan menggunakan Sales Promotion Girl, atau kegiatan-kegiatan off air yang bisa menarik banyak khalayak. Yang juga tidak kalah pentingnya adalah budget pengiklan dalam setahun. Nilai Rp.5 Miliar, menurut anggota Dewan Penasihat PPPI (Persatuan Perusahaan Periklanan Indonesia), 'nothing' bagi sebuah iklan di media massa; akan 
tetapi lanjutnya, "untuk kegiatan (jumlah itu) something". Dengan kata lain, seringkali menggunakan media massa pun bukan sebuah strategi yang tepat apabila segmentasi pasar dan anggarannya tidak sesuai.

Salah satu strategi lainnya disebutkan pria yang mengawali karier di Citra Lintas Advertising, "What to say-nya boleh sama, tapi caranya berbeda". Yang dimaksud dengan cara berbeda di sini adalah, pesan 'Selamat Pagi', akan berbeda 'rasa'-nya bagi khalayak di tanah Pasundan apabila disampaikan dengan 'Wilujeng Enjing'. Dalam pesan yang sama dari sebuah brand, bisa memiliki berbagai versi yang sekali lagi bergantung dari segmentasi khalayaknya. Artinya, ada unsur lokalitas, sisi etnografis khalayak yang harus dapat dilihat.

Komunikasi yang dilakukan oleh industri periklanan, baik pada lini atas maupun lini bawah, adalah komunikasi 'manipulatif'. Kreativitas sebagai strategi periklanan dalam menggaet perhatian khalayak sesungguhnya 'tidak lebih' dari manipulasi aspek kognisi khalayak tentang pesan iklan.

Di sinilah seringkali terjadi pertarungan ideologi. Melalui proses 'manipulasi' tersebut, di dalam diri khalayak ditanamkan suatu kebutuhan yang seolah-olah didasarkan pada habitus khalayak. NH memberi contoh Starbuck's. Di Amerika, di negara asalnya, konsumen mementingkan unsur 'instant' dalam memesan beverage. Mereka cenderung lebih menyukai take away, agar praktis dan cepat saji. Hampir di seluruh Starbuck's di Indonesia, menyediakan meja dan kursi untuk 'nongkrong'. Apa yang terjadi di sini adalah konsumen ingin seen and be seen. Ada keinginan konsumen untuk lebih dari sekedar duduk-duduk dan bercengkrama; tapi juga untuk dilihat bahwa harga Starbuck's yang sungguh di atas rata-rata untuk secangkir kopi dan macam-macam racikannya itu affordable untuk kantong-kantong mereka. Starbuck's lebih dari sekedar kopi, Starbuck's adalah status sosial. Starbuck's adalah habitus orang-orang kelas menengah yang 'menyerah kalah' pada strategi komunikasi Starbuck's.

Hal ini diakui pula oleh NH. Pekerjaan memasarkan secara terpadu memang pekerjaan manipulasi pikiran. Dan bagaimana cara memanipulasi itulah yang bergantung pada kreativitas pembuat iklan.

NH memberikan contoh kasus salah satu perusahaan bakery yang menjadi kliennya. Pada hari pertama pembukaan toko tersebut, perusahaannya meng-hire orang-orang 'biasa' untuk 'seolah-olah' antri membeli roti. Mereka tinggal mengambil sejumlah roti dan antri di depan kasir. Kondisi semacam ini membuat orang lain yang lewat dan melihat antrian tertarik ingin mengetahui. Apakah gerangan yang terjadi? Dan saat itulah terjadi proses yang dalam komunikasi disebut dengan AIDA (attraction, interest, desire, action). 'Atraksi' manipulatif tersebut ternyata sukses menarik calon konsumen lain untuk melihat, tertarik, menginginkan, dan kemudian membeli. 
Sangat menarik, menurut penulis, bagaimana strategi dan proses kreatif dalam industri periklanan ini dapat bukan saja mempengaruhi mindset mereka yang memang dijadikan target market. Lebih dari sekedar itu, bukan hanya target market sebuah brand yang pikirannya 'mempan' untuk dimanipulasi, akan tetapi hampir semua orang termanipulasi. Misalnya, tidak ada peraturan tertulis dimanapun di dunia ini bahwa perempuan itu harus langsing, berkulit putih bersih, berkaki panjang dan berambut panjang. Akan tetapi, mulai dari anak-anak sampai nenek-nenek pun mengetahui 'aturan' tersebut.

Artinya, selektivitas khalayak memang ada. Khalayak memang nyata-nyata memilah dan memilih informasi apa yang ingin mereka konsumsi, dari media mana dan bagaimana. Namun demikian, dalam proses memilah dan memilih informasi tersebut, mereka tidak akan pernah lepas dari pesan-pesan sponsor berbagai produk.

NH mengambil analogi dari kemampuan adaptasi dan fleksibilitas kecoa dan tikus. Kemampuan adaptasi dan fleksibilitas mereka itulah yang menyebabkan mereka tidak punah sampai sekarang ini. "Selama masih ada manusia, masih ada barang yang diperjualbelikan, iklan nggak akan mati. Perusahaan periklanan juga akan berevolusi setiap hari, disesuaikan dengan kebutuhan (khalayak pen.),"ujarnya.

\section{SIMPULAN}

Khalayak semakin selektif dari masa ke masa. Hal ini dipengaruhi oleh banyaknya jenis dan konten media baru yang bermunculan, sehingga memberikan khalayak lebih banyak pilihan. Selain itu, teknologi yang berkembang pesat juga membuat zaman semakin serba 'instant'. Untuk memenuhi tuntutan zaman yang serba cepat, khalayak harus memilih informasi mana yang mereka butuhkan. Hal ini diputuskan secara rasional.

Selektivitas khalayak ternyata tidak lantas membuat perusahaan iklan 'mati gaya' dalam menarik perhatian khalayak. Strategi yang saat ini dilakukan adalah dengan lebih fokus langsung kepada segmentasi pasarnya. Karena dalam periklanan, hal yang paling penting adalah khalayak. Periklanan akan selalu mengikuti insight khalayak dan keluar dengan sebuah foresight. Oleh karena itu, strategi komunikasi yang dilakukan oleh perusahaan pengiklan saat ini tidak lagi berfokus ke TV saja; akan tetapi mengikuti bentuk komunikasi yang tepat baik bagi perusahaan pemasang iklan maupun bagi khalayak dengan berbagai macam kondisinya internalnya (kondisi psikografis, demografis, etnografis, dll).

Walaupun saat ini TV masih merajai porsi belanja iklan, akan tetapi munculnya mediamedia baru juga tidak boleh diremehkan karena ke depannya social media networking 
akan semakin meningkat, sehingga pengiklan harus mulai memperhitungkan kekuatan social media network.

Khalayak boleh saja selektif dalam memilih informasi; akan tetapi kekuatan media sebagai ruang sosial dalam menanamkan ideologi tertentu pada khalayaknya juga sangat kuat. Artinya, iklan memiliki kekuatan untuk menanamkan ideologi melalui manipulasi pikiran khalayak terhadap brand tertentu yang menjadi pengiklannya. Pikiran tersebut berupa perasaan butuh terhadap brand tertentu yang mungkin lagi bukan merupakan kegunaannya akan tetapi sudah berupa kebutuhan akan pengakuan status sosial.

Artikel ini diharapkan dapat digunakan sebagai acuan, atau dasar bagi penelitianpenelitian yang akan melihat mengenai strategi industry periklanan di media baru yang geliatnya mulai tumbuh. Selain itu, artikel ini juga diharapkan dapat menambah khazanah mengenai kajian selektivitas khalayak dan interaksinya dengan media massa yang akan sangat bermanfaat bagi praktisi pemasaran dan pengiklan.

\section{DAFTAR PUSTAKA}

Admin. Anggota ATVLI. 2010. Sumber: http://www.atvli.com/anggota.asp, diakses pada 25 Maret 2010 pukul 22:06 WIB

Admin. Merayakan Animasi di Blankspot Area. 2009. Sumber: http://www.gatra.com/2009-11-15/artikel.php?id=132053, diakses pada 25 Maret 2010 pukul 22:47 WIB

Admin. Tahun Tidak Diketahui. Literature Review of Uses and Gratification Theory. Sumber: http://www.ou.edu/deptcomm/dodjcc/groups/00B2/LitReview.htm diakses pada 25 Maret 2010, pukul 19:52 WIB

Ashford, Jose B. dan Craig Winston Leroy. (2008). Human Behavior in The Social Environment Fourth Edition. Brooks/Cole, Cengage Learning: Belmont, CA.

Badriaty, Meily. Dominasi Pemilik Modal dan Resistensi Pekerja Media.(Jurnal Penelitian Ilmu Komunikasi. Volume V/No.1, edisi Jan-April 2006).

Elliot, Andrew J. dan Carol S. Dweck. (2005). Handbook of Competence and Motivation. The Guilford Press: New York dan London.

Ibrahim, Idi Subandy, ed. (1997). Lifestyle Ecstasy. Jalasutra: Yogyakarta.

Lister, Martin, Jon Dovey, Seth Giddings, Iain Grant, dan Kieran Kelly. (2003). New Media: A Critical Introduction. Routledge: London and New York.

Marketing Mix, edisi 03, Maret, 2010, hal.26. 
McQuail, Dennis. (2005). McQuail's Mass Communication Theory. Sagepub: USA.

Meurs, Lex Van. (1998). Switching During Commercial Breaks. Intomart: Netherlands.

Raymond Reynaldi. 2009. Total Belanja Iklan Oktober 2009 Sudah Mencapai Rp. 40 Triliun. Sumber: $\quad$ http://www.kontan.co.id/index.php/bisnis/news/26362/TotalBelanja-Iklan-Oktober-2009-sudah-Mencapai-Rp-40-triliun, diakses pada pada 28 Maret 2010, 18:07

Yang, Dr. Jin. Internet Dependency Relations and Internet News Exposure. 2008. Journal of New Communications Research, Volume II/Issue 2, Winter 2007 - 2008, SNCR Press: Palo Alto, CA. 